\title{
Perception of Medical Health College Students Toward Mental Health
}

\author{
Wiwik Widiyawati ${ }^{1}$, Ah Yusuf ${ }^{2}$, Indra Fajar Ibnu ${ }^{3}$ \\ ${ }^{1}$ Doctoral Degree Student of Faculty of Public Health Unair Surabaya, Lecturer of Faculty of Public Health, \\ Universitas Muhammadiyah, Gresik, Indonesia, ${ }^{2}$ Faculty of Ners, Universitas Airlangga (60115), Surabaya, \\ Indonesia, ${ }^{3}$ Faculty of Public Health, Universitas Hasanuddin, Makassar, Indonesia
}

\begin{abstract}
Background: Mental health is a major that often gets bad perception. Bad perceptions of mental health often occur in special populations (students). It is necessary to measure student perceptions to describe their perceptions regarding mental health

Objective : To describe student perceptions (aspects of cognition, aspects of affection and aspects of conation) about mental health.

Method: This study uses quantitative method with descriptive approach. The sample of this study are 100 college students of Public health major in UIN Alauddin, Makassar,

Result: In general, cognitive aspect of respondents is positive, as well as psychomotoric and affection aspect.

Conclusion : Students' perceptions related to mental health after measurement tend to be good for all three aspects (cognition, affection and conation) without one statement having the largest negative percentage.
\end{abstract}

Keywords: mental health, medical students, cognition, affection, conation

\section{Introduction}

Mental health problems are one of the public health problems that must get more attention. The number of patients with mental health problems keeps increasing which is estimated at 450 million people worldwide (World Health Organization, 2013). In Indonesia, mental health problems also become a serious case, because there is a significant increase in number of mental health problem patients from 2 cases per mile in 2013 to 7 cases per mile in 2018. Mental health sufferers often get poor treatment. People who suffer from mental disorders often get negative and bad views and are often seen as

\section{Corresponding author:}

\section{Ah Yusuf}

Faculty of Ners, Universitas Airlangga (60115),

Surabaya, Indonesia ${ }^{2 *}$

+628123298571, ah-yusuf@fkp.unair.ac.id frightening ${ }^{1}$.

Negative perceptions of mental health not only arise in common people who have minimal knowledge related to mental health, but also arise in certain group, such as medical employees and students who incidentally have better knowledge about medic. Sometimes, students of public health also have negative and mistaken perceptions of mental health. Happell et al on their study state that there are still many first-year students who still have unfavorable perceptions of mental health and result in their lack of attention to mental health that they may experience bias in college ${ }^{2}$.

Medical students must have a positive perception of mental health because this will affect the future of mental health services. Students who are currently conducting lectures will become health professionals in the future who are professional and have high integrity. 
When students, especially in the field of health, have improved their perceptions and have positive perceptions related to mental health, it is hoped that when they have completed their education they can become good health workers, especially in patients experiencing mental health problems ${ }^{3}$.

Medical students must have a good perception of mental health. Moreover, students also must be able to prevent the emergence of mental health problems in the community. However, if it does not have a good perception it can affect the intervention process that occurs. To avoid this, it is necessary to conduct research related to public health students' perceptions to determine student perceptions related to mental health. Based on this, the purpose of this study is to identify perceptions about mental health in public health students.

\section{Method of the Study}

This study uses quantitative design with the descriptive technique for approaching the issue. This study was conducted in June - July 2018 at the Faculty of Medicine and Health Sciences, Alauddin State Islamic University, Makassar. Populations of this study are all students of the public health study program at Alauddin State Islamic University Makassar. This study uses Proportional Random Sampling Technique. Sample are selected using inclusion criteria, namely (1) Health faculty students of 2017; (2) was in the location when the research took place; (3) willing to be a research respondent. Selected sample respondents are 100 people, consisting of 25 people from classes A and C, 24 people from class B, and 26 people from class $\mathrm{D}^{4}$.
Data collection was carried out directly by conducting interviews with respondents using instruments that had been prepared. Data collection was carried out for 2 months, starting from June 1, 2018 until July 30, 2018. Variable characteristics of respondents are collected included age, gender, type of residence of the respondent. Socio demographic variables are collected using a questionnaire independently, created by the researcher. Nurse perception variables based on aspects of cognition are measured using a questionnaire prepared by researchers. The questionnaire to measure this consists of 10 question items ${ }^{5}$.

This questionnaire is rated on a Likert scale, which are Strongly Agree, Agree, Disagree and Strongly Disagree. The data of reliability test results of the questionnaire of cognitive are analyzed using Cronbach Alpha. The reliability result shows the number of 0.810 , means that the questionnaire is reliable enough to be used for research instrument. Nurse perception variables based on affection aspects were measured using a questionnaire prepared by researchers. The questionnaire to measure this consisted of 14 question items ${ }^{6}$. The reliability test results of the questionnaire using Cronbach Alpha showed the number 0.81, so it can be said that the questionnaire is reliable for use as a research instrument ${ }^{7}$.

Data analysis was carried out univariably, with the aim of describing the characteristics of the variables. Analysis of variables with a numerical data scale is then displayed in the form of mean and standard deviation. The data then are poured in the form of a description, while for each question item is displayed in the form of a percentage ${ }^{8}$.

\section{Result}

Table 1. Distribution of Perception in students from cognitive aspect

\begin{tabular}{|c|c|c|c|c|c|c|c|c|}
\hline \multirow{2}{*}{ Question } & \multicolumn{2}{|l|}{ SS } & \multicolumn{2}{|l|}{ S } & \multicolumn{2}{|c|}{ TS } & \multicolumn{2}{|c|}{ STSS } \\
\hline & $\mathbf{N}$ & $\%$ & $\mathbf{n}$ & $\%$ & $\mathbf{n}$ & $\%$ & $\mathbf{n}$ & $\%$ \\
\hline $\begin{array}{l}\text { I understand people who have mentality } \\
\text { healthy ones are able to work well }\end{array}$ & 46 & 46 & 39 & 39 & 12 & 12 & 3 & 3 \\
\hline $\begin{array}{l}\text { Often think things that are unrealistic and daydreaming can interfere with } \\
\text { one's mental health }\end{array}$ & 15 & 15 & 55 & 55 & 25 & 25 & 5 & 5 \\
\hline
\end{tabular}


Cont... Table 1. Distribution of Perception in students from cognitive aspect

\begin{tabular}{|c|c|c|c|c|c|c|c|c|}
\hline $\begin{array}{l}\text { I understand that people who have a healthy mentality will not cheat to win } \\
\text { a race }\end{array}$ & 29 & 29 & 53 & 53 & 14 & 14 & 4 & 4 \\
\hline $\begin{array}{l}\text { I understand people who often get angry don't interfere with their mental } \\
\text { health }\end{array}$ & 6 & 6 & 21 & 21 & 55 & 55 & 18 & 18 \\
\hline Peace of mind can arise due to positive feelings & 52 & 52 & 44 & 44 & 4 & 4 & 0 & 0 \\
\hline $\begin{array}{l}\text { I understand that mentally healthy people can control their attitudes even } \\
\text { when they are stressed }\end{array}$ & 26 & 26 & 63 & 63 & 8 & 8 & 3 & 3 \\
\hline People who are confident can interfere with mental health & 0 & 0 & 12 & 12 & 58 & 58 & 30 & 30 \\
\hline People who have erratic positions can influence their self-concept & 15 & 15 & 70 & 70 & 9 & 9 & 6 & 6 \\
\hline $\begin{array}{l}\text { I understand that people with mental disorders are people who refuse or } \\
\text { run away from the reality of their lives }\end{array}$ & 13 & 13 & 53 & 53 & 32 & 32 & 2 & 2 \\
\hline $\begin{array}{l}\text { Rejecting the reality of life at hand does not interfere with his mental } \\
\text { health }\end{array}$ & 5 & 5 & 17 & 17 & 66 & 66 & 12 & 12 \\
\hline
\end{tabular}

Table 1 shows the distribution of students' perceptions based on aspects of cognition. Most respondents have the opinion that strongly agrees (46\%) that mentally healthy people can work well. Most of the respondents also agreed (55\%) about the opinion that the high imagination can cause mental health problems. Most respondents agreed (53\%) with the statement that mentally healthy people can control themselves from cheating. Most respondents disagreed (55\%) about the statement that being angry often did not interfere with mental health. Most respondents expressed strongly agree $(52 \%)$ to the statement that positive feelings are caused by peace of mind. Most respondents felt agree (63\%) of mind control statements can be done well by mentally healthy people. As many as $58 \%$ of respondents disagree with the statement that feeling too high in selfconfidence can interfere with one's mental health. As many as $70 \%$ of respondents agree with the statement that people who do not have a good stance can influence their self-concept. Most respondents agreed (53\%) with the statement that people tend to experience mental disorders when melting themselves from the reality of life. Most respondents disagreed (66\%) with statements about the rejection of the fact of life does not interfere with mental health.

Table 2. Distribution of Perception in students from affective aspect

\begin{tabular}{|c|c|c|c|c|c|c|c|c|}
\hline \multirow{2}{*}{ Question } & \multicolumn{2}{|l|}{ SS } & \multicolumn{2}{|l|}{$\mathrm{S}$} & \multicolumn{2}{|l|}{ TS } & \multicolumn{2}{|c|}{ STSS } \\
\hline & $\mathrm{N}$ & $\%$ & $\mathrm{n}$ & $\%$ & $\mathrm{n}$ & $\%$ & $\mathrm{n}$ & $\%$ \\
\hline I feel satisfied while doing everything I do efficiently & 58 & 58 & 38 & 38 & 2 & 2 & 2 & 2 \\
\hline I feel under pressure when I have a lot of work piled up & 16 & 16 & 51 & 51 & 24 & 24 & 9 & 9 \\
\hline $\begin{array}{l}\text { I feel not disappointed when the activities that I do do not go according to } \\
\text { the plan that has been arranged }\end{array}$ & 8 & 8 & 24 & 24 & 54 & 54 & 14 & 14 \\
\hline $\begin{array}{l}\text { I do not feel satisfied at all when being able to do more than one job at the } \\
\text { same time }\end{array}$ & 6 & 6 & 14 & 14 & 63 & 63 & 17 & 17 \\
\hline I feel jealous when my friends are very close to each other & 2 & 2 & 14 & 14 & 51 & 51 & 33 & 33 \\
\hline
\end{tabular}


Cont... Table 2. Distribution of Perception in students from affective aspect

\begin{tabular}{|c|c|c|c|c|c|c|c|c|}
\hline $\begin{array}{l}\text { I feel satisfied when I can control my emotionweel, so I don't get angry } \\
\text { when there is a quarrel }\end{array}$ & 51 & 51 & 46 & 46 & 3 & 3 & 0 & 0 \\
\hline I feel happy when I am able to solve every problem calmly (without haste) & 67 & 67 & 29 & 29 & 4 & 4 & 0 & 0 \\
\hline I feel sorry for people who hate each other & 31 & 31 & 55 & 55 & 11 & 11 & 3 & 3 \\
\hline $\begin{array}{l}\text { Feeling inferior will not affect self-concept (the views and attitudes of } \\
\text { individuals towards themselves) }\end{array}$ & 7 & 7 & 33 & 33 & 46 & 46 & 14 & 14 \\
\hline $\begin{array}{l}\text { I feel confident when dressing comfortably and decently without } \\
\text { following trends }\end{array}$ & 52 & 52 & 45 & 45 & 3 & 3 & 0 & 0 \\
\hline I feel happy when I am able to do everything properly & 59 & 59 & 39 & 39 & 2 & 2 & 0 & 0 \\
\hline $\begin{array}{l}\text { I feel worried when I am unable to adapt to the campus environment as a } \\
\text { new student }\end{array}$ & 26 & 26 & 57 & 57 & 14 & 14 & 3 & 3 \\
\hline I feel worried for people who can't accept the reality of their lives & 24 & 24 & 69 & 69 & 6 & 6 & 1 & 1 \\
\hline $\begin{array}{l}\text { I don't feel any satisfaction when I am able to solve personal problems } \\
\text { without involving others }\end{array}$ & 4 & 4 & 20 & 20 & 68 & 68 & 8 & 8 \\
\hline
\end{tabular}

Table 2 shows the distribution of students' perceptions based on aspects of affection. Most respondents have an opinion that strongly agrees (58\%) that respondents are satisfied with work efficiency. Most respondents agreed (51\%) about opinions which stated that respondents felt depressed over the pile of work. Most respondents stated disagree (54\%) with the statement that the respondent felt disappointed when the activity did not run smoothly. Most respondents disagreed (63\%) about the statement that respondents felt dissatisfied when able to do 2 work together. Most respondents said that they did not agree (51\%) to the statement that the respondents felt jealous of the closeness of their friends. Most respondents felt strongly agree $(51 \%)$ to the statement that the respondent was satisfied when successfully controlling emotions.

Total $67 \%$ of respondents strongly agree when able to solve problems calmly. There are as $55 \%$ of respondents agreed with the statement that respondents felt sorry for people who hate each other. Most respondents felt disagree $(46 \%)$ to the statement that he felt inferior would affect the self-concept. Most of the respondents strongly agreed to agree (52\%) with the statement that respondents felt confident when dressing modestly even though they did not follow trends. respondents agreed (59\%) with a statement he felt happy when able to do things according to his nature. As many as $57 \%$ of respondents agreed with the statement that the respondents felt worried not being able to adapt in the campus environment. Most of the respondents felt agree $(69 \%)$ to the statement themselves feel worried about people who can not accept the reality of his life. Most of the respondents disagreed (68\%) towards the statement saying that the respondent felt dissatisfied when able to solve personal problems.

\section{Discussion}

The aspect of cognition becomes one of the aspects of perception consisting of knowledge. Knowledge possessed by someone is influenced by individual experience. The higher the knowledge ssomeone possessed, the more likely it will be to have a positive perception. But not always someone who has high knowledge also has a positive perception but can also have a negative perception. From the result above, it can be seen that the majority of respondents already have a good perception of mental health. Respondents can choose answers to statements in accordance with the nature of the question, answer agree or strongly agree to positive questions and vice versa ${ }^{9}$. 
People whose mental state is not good can influence their self-perception, so that it will affect their mindset, such as difficult to concentrate, apathetic, and difficult to carry out the planned activities. The positive thinking can have a good impact on the mental of students, so that they can adapt well to the environment as medical student. Campus life is a transition between adolescents towards maturity, so that students need see a realistic view of the world and see their limitations as an advantage ${ }^{10}$.

Kulshrestha in his tsudy states that where students 'perceptions of mental health are strongly influenced by students' knowledge, regarding mental health. The higher the knowledge they have the more positive their perception will be. Students are expected to have good knowledge gained during the study process and have enough experience, so that they can become competent medical team when entering workforce ${ }^{11}$.

Next is the aspect of affection. Affection aspects are composed of emotions and feelings that arise in certain phenomena and objects. The results above shows that respondents have positive affection. This is proofed by the condition of respondents who can recognize themselves, have a good self-concept. Ramchandra in his study states that emotions and feelings are one of the important things that influence the formation of students' perceptions of people with mental health. When a student has good well being and does not have a guilty state on him, he will have good mental health and be able to deal with problems that arise in his life ${ }^{12}$.

\section{Conclusion}

Based on the result above, it can be concluded that the perceptions students have of mental health tend to be positive. There is not a single question that has a negative response to the most choices, which means negative responses are only given by a small portion of students. This is expected to become insight for enlightment to make improvements to some students who still have negative or unfavorable perception of mental health.

Ethical Clearance: The research process involves participants in the survey using a questionnaire that was accordant with the ethical research principle based on the regulation of research ethic committee. The present study was carried out in accordance with the research principles. This study implemented the basic principle ethics of respect, beneficence, nonmaleficence, and justice.

Conflict of Interest: The author reports no conflict of interest of this work.

Source of Funding: This study is done with individual funding.

\section{References}

1. Whitney DG, Peterson MD. US national and statelevel prevalence of mental health disorders and disparities of mental health care use in children. JAMA Pediatr. 2019;173(4):389-91.

2. Happell B, Waks S, Bocking J, Horgan A, Manning F, Greaney S, et al. 'There's more to a person than what's in front of you': Nursing students' experiences of consumer taught mental health education. Int J Ment Health Nurs. 2019;28(4):9509.

3. Volpe U, Ventriglio A, Bellomo A, Kadhum M, Lewis T, Molodynski A, et al. Mental health and wellbeing among Italian medical students: A descriptive study. Int Rev psychiatry. 2019;31(78):569-73.

4. Joeliantina A, Agil M, Qomaruddin MB, Soedirham O. Family Support for Diabetes Selfcare Behavior in T2DM Patients who Use Herbs as a Complementary Treatment. Medico-Legal Updat. 2019;19(1).

5. Ozturan O, Senturk E, Iraz M, Ceylan AN, Idin K, Doğan R, et al. Nasal care in intensive care unit patients. Intensive Crit Care Nurs. 2018;44:36-9.

6. Nursalam N, Octavia M, Tristiana RD, Efendi F. Association between insomnia and social network site use in Indonesian adolescents. In: Nursing forum. Wiley Online Library; 2019. p. 149-56.

7. Ahsan A, Nursalam N, Efendi F. Model Development of Nursing Service Loyalty. Indian J Public Heal Res Dev. 2019;10(1).

8. Gu J-A, Choi A-S, Kim H-G. Applying the Havruta Learning Method to Nursing Education. MedicoLegal Updat. 2019;19(1):653-8.

9. Frick A, Möhring W, Newcombe NS. Development of mental transformation abilities. Trends Cogn Sci. 2014;18(10):536-42.

10. Campbell K, Massey D, Broadbent M, Clarke K. 
Factors influencing clinical decision making used by mental health nurses to provide provisional diagnosis: A scoping review. Int J Ment Health Nurs. 2019;28(2):407-24.

11. Kulshrestha P, Sharma RK, Dogra TD. The study of sociological and demographical variables of unnatural deaths among young women in South Delhi within seven years of marriage. MedicoLegal Updat. 2004;4(1):5-14.

12. Ramchandra DS. Informed Consent: A Myth of Ethical Spirit and Legal Paradigm in Medical Profession. Medico-Legal Updat. 2014;14(1):8690. 